\title{
The Paradox of Global Norms
}

\section{Caterina GARCÍA, Pablo PAREJA \& Ángel J. RODRIGO*}

\section{(I) INTRODUCTION}

The need to create global rules to address global problems or challenges (climate change, international migration, biodiversity reduction, activities in cyberspace and even outer space), to protect global common resources and to provide global public goods is increasingly pressing. However, this demand contrasts with an international practice in which it is complicated and sometimes very difficult to adopt new global norms. This is a critical paradox as global norms are more necessary than ever but at the same time more difficult to adopt. Describing, understanding and explaining this paradox was the aim of the research project on The creation of global norms: between soft cosmopolitanism and the revitalization of Westphalia that was developed by a group of researchers at the Universitat Pompeu Fabra between 2017 and 2021 . This group is characterized by two features. The first is its international composition, as its members come from six different nationalities. The second is its interdisciplinary approach, mostly combining International Law and International Relations. This interdisciplinary perspective is a feature that has characterized the group for many years and which, we believe, provides mutual benefits both to the members of the group and to the resulting work produced by each of them.

The purpose of this paper is twofold: on the one hand, it seeks to provide a synthesis of the preliminary work developed to facilitate the design and implementation of the research project ${ }^{1}$; on the other hand, it aims at introducing and contextualizing the different case studies included in this Forum.

Attempting to understand, describe and analyze the paradox resulting from the growing need for global norms and the reluctance or inability of international actors to adopt them requires three complementary components: first, to build a common understanding of global norms; second, to contextualize the process of creation and its difficulties in an international community in which two underlying trends — soft cosmopolitanism and a certain Westphalian resurgence in international relations - coincide and coexist; and, finally, to identify some of the hypotheses on which the project is based and which need to be confirmed, refuted or nuanced.

\section{(II) A BROAD CONCEPTION OF GLOBAL NORM-SETTING}

The project was based on a broad conception of the notion of global standard-setting. Such conception has the potential to be more effective because it allows for the plural, different approaches that the participant members may have. In essence, it is characterized by the following features (C. Brölman \& Y. Radi, 2018, p. 2):

1. The notion of norms does not necessarily require a binary classification between law and non-law. In International Relations, the concept of Global Norms refers very broadly to "shared expectations or standards

\footnotetext{
* Professor and Associate Professors of Public International Law, University Pompeu Fabra.

1 C. García, P. Pareja \& A.J. Rodrigo, La creación de normas globales: entre el cosmopolitismo soft y el resurgir de Westfalia, Orbis Working Papers, 2019/08.
} 
of appropriate conduct accepted by states, international governmental organizations and/or non-governmental actors of various kinds" (Khagram, Viker \& Sikkink, 2002). In legal science, it is possible to understand legal normativity as a sliding scale (Ch. Chinkin, 1989, p. 850), in which a gradation of legal effects can be identified. This conception can help to examine more formalized rule-making processes (international treaties), but also others in which general rules of conduct are adopted (e.g. codes of conduct or draft conclusions).

2. The term norm-setting encompasses a variety of norm-setting procedures and processes. Four avenues of global norm-setting can be identified: a) legal norm-setting, b) multiple stakeholder initiatives, c) global policy networks, and d) transnational advocacy coalitions (Martinsson, 2011).

In the case of legal norm creation, these include: a) Formalized procedures of international legal norm creation such as international treaties or resolutions of international organizations; b) Other diffuse processes of interaction between legal actors such as standards, codes of conduct, etc.; and c) Social processes in which legal consequences can be induced from certain social practices (international custom).

3. The term global includes normative activity that transcends national legal borders. In addition, it is not limited to the classic inter-state framework. Finally, it helps to incorporate, even tacitly, the aspiration for universality of norms that seek to regulate and protect the global public interest and cosmopolitan values that have an undeniably global dimension.

4. The progressive blurring of the boundaries between diffusion and change of and in norms. Along with the above features, the notion of global norm setting is also characterized by the gradual interpenetration and reconstitution of the processes of diffusion and change of global norms. Diffusion refers to the process by which the observation and acceptance of particular norms spread beyond the group of actors proposing them and attain a universal or near-universal dimension. In contrast, change refers to the process through which norms undergo variations with respect to factors such as their level of precision or their scope, and which may result either in the transformation (or adaptation) of existing norms or in their replacement by different, new ones. Although these two processes are distinguishable from a theoretical point of view, in practice the two of them not only run simultaneously, but also maintain an intense relationship of reciprocal influence that informs their development.

\section{(III) THE COEXISTENCE OF SOFT COSMOPOLITANISM AND WESTPHALIAN REVIVALISM}

The analysis of the creation and transformation of global norms takes place in an international context characterized by the coexistence of two processes that, in part, can be seen as opposing signs: on the one hand, the advance of a soft cosmopolitanism that has not yet taken hold but has proved more resilient than some of its critics predicted at the beginning of the 1990s; and, on the other, the more recent resurgence of discourses and behaviors close to a partially weakened Westphalian model that seeks to regain space. This Westphalian model is accompanied by state behavior described as a "return to geopolitics" (Mead, 2014, Guzzini, 2013), which adopts foreign policy models typical of realist power politics and moves away from liberal models and conceptions of international order.

The tension between these two processes or phenomena has multiple and profound repercussions on international relations in the constitutional order built since the Second World War, and on international law as one of its fundamental institutions (García \& Pareja, 2016). However, it is in the processes of normative construction where its effects are most evident in the short term, making them privileged scenarios for analyzing and understanding the potential impact of this tension in the medium and long term. Hence, the content of the project was delimited and informed by the two aforementioned trends: a) the advance of soft cosmopolitanism and the consequent articulation of global norms and a truly public international law; and b) 
the revitalization of the Westphalian model, the re-emergence of the state and the defense of the classical version of state sovereignty and its translation into behaviors based on geopolitical conceptions.

\section{(1) The advance of soft cosmopolitanism, the advance of other mechanisms of global governance and the consolidation of a public dimension in international law}

\section{(a) The advance of soft cosmopolitanism}

Following decades of neglect, cosmopolitanism burst into the theoretical reflections of the social and legal sciences after the end of the Cold War. This was helped, on the one hand, by the realization of the global and transnational nature of some of the main challenges facing contemporary international society and, on the other, by an awareness of the need to create patterns of global governance in order to manage them effectively. The resulting "cosmopolitan turn" entailed the abandonment -politically and intellectually- of the limitations of the national imaginary, as well as the embrace of ideological, political and legal developments that question the supremacy of state sovereignty and claim the tension between human rights and states' rights (Beck, 2005). In their early days, many of these developments were strongly influenced by a liberal conception of the state and the liberal order in which global governance replaced the state (Krieger, 2017). Over the years, however, resistance to this shift has led to continuous back-and-forth, and rhetorical advances have often been followed by sharp reversals in the political-practical sphere. It is not surprising, then, that a kind of soft cosmopolitanism has gradually taken hold.

This cosmopolitanism is characterized by three main features. The first is its asymmetrical or variable level of rootedness in different regions of the world. Although it is more firmly established among Western countries and somewhat less so in most emerging powers, the differences within each of these groups are notable and it seems imprecise to speak of more or less cosmopolitan regions. The second is the existence of a gap between the rhetorical defense of cosmopolitan principles and their translation into specific, precise norms, a gap that partly reflects the conception of the cosmopolitan corpus more as an ideal or source of inspiration than as a programmatic guide. The third is its commitment to reconciling the preservation of the state and its interests as central elements of international society with the gradual articulation of mechanisms and instruments that respond to the cosmopolitan will to offer universal, general and individual-centered responses (Gallaroti, 2010).

\section{(b) The advance of global governance' mechanisms: the international liberal order}

From the ideas, principles and approaches associated with this soft cosmopolitanism sponsored by international actors and institutions emerge global governance projects that can be understood as part of a longterm process or a long-term trend. These global governance mechanisms are embedded in the international order built after the Second World War, an order that combines contractual elements with others of a hegemonic nature. The essence of this international order can be summarized in five convictions (Ikenberry, 2018: 11). First, a strong preference for openness: trade and exchanges are not only perceived as two defining features of today's global society, but also as two factors that promote economic development, peace and the advancement of democracy. Second, a strong commitment to a system of international relations based on the observance and enforcement of an evolving set of principles, norms and rules. Third, a widespread belief in the need to maintain a minimum level of security cooperation to ensure the survival of the actors and the system they comprise. Fourth, the conviction that the current international order is flexible and correctable, that is, capable of adapting to the changing circumstances and demands of the international system that underlies it. Finally, a deep hope that this order embodies an idea of progress that contributes to the advancement of liberal democracy across the globe.

The emergence and advancement of new mechanisms of global governance has been facilitated in recent years by the transformation of the international order, a transformation that has given rise to a "decentralized or center-less globalism" (Buzan and Lawson, 2015: 273-304). Barry Buzan and George Lawson suggest that we now live in an international society in which regions occupy a central position and in which there are no 
longer undisputed superpowers. They also believe that we are moving towards an international order characterized by five elements: firstly, the diversity and diffusion of power among a wide range of actors, both state and non-state; secondly, the overlapping and interpenetration of multiple forms of interaction that transcend classical inter-state international relations; third, the coexistence of a wide range of domestic governance models and organizational practices; fourth, the replacement of US/Western hegemony by a decentralized or polycentric system; and finally, fifth, the progressive weakening of the conception of liberal values as universal values.

\section{(c) The consolidation of a public dimension within International Law.}

This process of advancing soft cosmopolitanism has been accompanied by the creation of global governance mechanisms that have contributed to the evolution of the international legal order. In this regard, and in order to better organize and regulate the cosmopolitan interests and values shared in the world system, several fundamental legal norms have been adopted that limit the power of states, recognize the rights and freedoms of individuals, allow for accountability for violations of these that constitute crimes against humanity, and protect the general interests of international society. Their impact on global society and international law has been explained by different doctrinal currents through international constitutionalism (Peters, Klabbers and Ulfstein, 2009), global administrative law (Kingsbury, 2005), perspectives such as International Public Authority (Von Bogdangy et al. 2010) or through the International Rule of Law (Nolte and Krieger, 2016).

Together with other factors, the challenge of soft cosmopolitanism to classical public international law has contributed to its evolution towards a truly public international law (Casanovas, 2015, Rodrigo, 2019, and Casanovas and Rodrigo, 2021). This legal order now has a public dimension that is characterized by four elements. First, it is a public international law because one of its primary purposes is the protection and regulation of the general interests of the international community, of the global public interest (Bouza, García and Rodrigo, 2015). Secondly, it is a public international law that has seen its classic functions increased to also include that of regulating and protecting the general interests of the international community by means of new types of rules, public interest rules (Huesa, 2015; Delbrück, 1997; Rodrigo, 2019), and international obligations (obligations of integral structure and interdependent obligations) that have given rise to a community structure in the international legal order. Third, the international legal order has become an inclusive international legal system that allows for the participation of non-state actors at certain levels and in certain spaces (MacCorquodale, 2004). Fourthly, the global public interest is regulated and protected by public interest norms that operate within the framework of general international regimes (Casanovas and Rodrigo, 2021 ); it is therefore a genuinely public international law because it not only regulates relations between public entities (states), but also protects and regulates the public interest of the international community as a whole. Finally, public international law is characterized by the fact that it is a more complex and more mature legal system than its previous version, because it performs a greater number of functions and because, in addition to its traditional structure, it also has a community structure, which now has an increasingly complete community toolbox that allows it to maintain its formal and material unity.

In addition to the evolution of classical public international law towards a truly public one, soft cosmopolitanism drives the creation of global norms, understood as standards of conduct, which apply to transnational identity groups and which, although they do not always create legal rules and principles, help to establish norms and expectations of conduct. In other words, they introduce cosmopolitan elements into the liberal international order.

\section{(2) The revival of the Westphalian model: the return of geopolitics, the re-emergence of the state and the defense of the classical version of state sovereignty}

In contrast to the advance of transformative soft cosmopolitanism and the crystallization of a public dimension within International Law described in the previous paragraphs, the last decade has also witnessed a 
revitalization of Westphalian conceptions of reality and the international legal order. Thus, the onset of the global economic crisis in 2007 and the subsequent political, economic, social and legal responses offer some signs of a possible change of trend or, at least, of the end of the belief in the existence of linear progress in international relations, international law and history (Peñas, 2012), from euphoria and confidence in progress to contestation (A. Wiener, 2014).

\section{(a)The revival of Westphalia and the return of geopolitics}

Andrew Hurrell has recently identified three possible signs of a possible 'change of cycle'. The first is the socalled 'return of geopolitics', evident in conflicts as diverse as Syria, Crimea, the South China Sea and eastern Ukraine. This return alludes to the growing weight of geostrategic considerations or realistic calculations in the international strategies of the great powers, the emphasis on the material sources of power and the return to conceptions of international reality that equate it with a system in constant competition. The second sign refers to the "shifting legitimacy problem arising from changes in the international distribution of power and the slowness with which these are reflected in the processes of international cooperation/negotiation", a problem whose effects are particularly reflected in the construction of norms in the international arena. Finally, the third sign concerns the 'power shift' in the world, a power that is shifting away from the core of the Western industrialized world (Hurrell, 2017), becoming increasingly fragmented and distributed among more actors and authorities of different natures (Acharya, 2014).

The factors that feed these signs or indicators of change are of a different nature: some consist of a change in economic conditions (rise of China, global financial crisis, evolution of the situation of the middle classes in developed and developing countries, etc.); others reflect changes in domestic political conditions (Trump's presidency in the United States, Brexit, populism in European countries, etc.); still others reflect changes in domestic political conditions (Trump's presidency in the United States, Brexit, populism in European countries, etc.); still others reflect changes in the political situation in Europe and the United States (Trump, Brexit, populism in the United States, etc.). These and other factors like the recent Covid-19 pandemic have favored the return of geopolitics, which has put territorial issues, power relations and threats of the use of force back at the center of the international agenda (Mead, 2014; Drezner, 2021). The revival of geopolitics has ultimately led to a re-securitization of the international relations agenda, which has been explained, rather than for deterministic reasons, by the identity crises of the main actors in international relations (Guzzini, 2013).

\section{(b)A shift in the redistribution of power: the re-emergence of the sovereign state}

The sum of these factors not only challenges the advance of soft cosmopolitanism, but also produces a redistribution of power in international law (Burke-White, 2015; Nolte and Kieger, 2016) that marks the end of the transatlantic moment and alters the processes and content of international law. These changes are structural and substantive. The new power structure can be synthesized in three essential features: power is diffuse, disaggregated and asymmetrically distributed. These characteristics result in a system that is not unipolar, bipolar or multipolar, but rather a complex multipolar system (García Segura 2014) or a multi-hub system (Burke-White 2015), which stimulates pluralism and drives some processes of international law.

From a substantive point of view, on the other hand, the growing influence of emerging powers has not translated into a rejection of the liberal international order, nor of public international law of which it is a fundamental element, nor into a clear break with the dominant transatlantic vision. The attitude of the so-called BRICs is illustrative in this respect: often accused of being subversive or even antagonistic (subversive leaders), their positions over the last decade vis-à-vis the evolution of the international legal order towards a genuine public international law make them pro-status quo states (García, 2017 \& 2019). They have become active supporters of Westphalian norms, leaving behind their traditional role as passive supporters (Sun, 2013). 


\section{(IV) PROJECT HYPOTHESIS}

The hypotheses on which the project has been built and on which confirmation and/or refutation has been sought are five:

a) The advance of soft cosmopolitanism is an established reality that, despite the challenge posed by the resurgence of Westphalian conceptions, has permeated contemporary international society and is more resilient than its detractors seem to recognize. Moreover, there is growing support among different members of the international community to the idea that many problems and challenges have a global dimension and that responses to them, either for the management of global common resources or for the creation of global public goods, must also be global.

b) The resurgence of conceptions linked to the Westphalian model has once again placed the state at the center of global norm-building processes, but has not succeeded in restoring its control or exclusivity over them. These processes are now more plural and open, and it is not possible to reconstruct them without taking into account the influence and contributions of non-state actors and private authorities in all areas of international reality, including those which, due to their impact on the principle of sovereignty, might seem more protected from the influence of non-state actors. Case studies should bring to light the increasing difficulties states face in reaching legally binding multilateral agreements with robust substantive normative content.

c) Global norm-building processes are best understood as dynamic, multidirectional, non-cumulative and plural processes that not only influence each other, but often run in parallel and intermingle, to the extent that in practice it is impossible to distinguish the processes of defining and disseminating global norms from those of transforming and replacing them.

d) The redefinition of global norm-building processes shows the challenges that public international law has to face as a fundamental institution of the international order and, in turn, contributes to the adaptation of the latter, which is increasingly proving to be "sticky" (Ikenberry, 2011). From this perspective, the reconstitution and interpenetration of the processes of global norm creation and diffusion, on the one hand, and those of norm transformation and substitution, on the other hand, should be interpreted as a further step in the stabilization of an increasingly less state-centered but nonetheless robust international order. Again, case studies should show that global norm-building processes help the consolidation and resilience of the public dimension of the international order and of an international law and an international order with cosmopolitan elements.

\section{(V) THE CREATION OF GLOBAL NORMS IN PRAXIS}

Among the papers elaborated in the implementation of the research project and which were presented at the Seminar held throughout the 2020-2021 academic year, this volume includes a representative selection. In her work "Between Cosmopolitism and Westphalia: the case of terrorism", Laura Planas shows how, despite the fact that terrorism has become one of the serious threats to international peace and security, there are serious difficulties in adopting global norms (including the definition of terrorism itself).

Meijie Jiang's paper, "Evolving China in the Global Climate Norm-Making: Development Models, National Roles and International Contexts", explains the process of shaping China's positions, practice and choices in the processes of negotiating and adopting norms to address climate change. It is a good example of the tense coexistence between the needs arising from cosmopolitanism and the resurgence of state interests.

In "Submarine Cables as an Object of Legal Regulation under International Law", Daria Shvets argues that submarine cables are a global public interest that should be protected and regulated by global rules. However, given that there are significant difficulties in adopting such rules, the author explores different options.

Josep Ibañez's contribution, "The normative dimension of platform governance: big techs and digital platforms as normative actors", highlights the relevance of the normative dimension of cyberspace governance 
in which states appear as dysfunctional entities. In it, big tech and social platforms have become normative actors through codes, algorithms and economic models.

Finally, Esteban Muñoz's work shows the potential normative significance of the ICJ through notions of de facto authority and inherent powers theory.

\section{REFERENCES (SELECTION)}

Bouza, N., García, C. y Rodrigo, A.J. (dirs.) y Pareja, P. (coord.) (2015), La gobernanza del interés público global, Madrid, Tecnos.

Brölman, C. y Radi, Y (2016), "Introduction: International lawmaking in a global world", en C. Bröllman and Y. Radi (Eds.), Research Handbook on the Theory and Practice of International Law-Making, Cheltenham/Northhampton: Edward Elgar Publishing, pp. 19.

Buzan, Barry y Lawson, George (2015), The Global Transformation. History, Modernity and the

Casanovas, O. (2015), "La dimensión pública del Derecho internacional actual”, en N. Bouza, C. García y A.J. Rodrigo (dirs.) y P. Pareja (coord.), La gobernanza del interés público global, Madrid, Tecnos, pp. 57-75.

Casanovas, O. y Rodrigo, A.J. (2021), Compendio de Derecho internacional Público, $10^{\text {aa }}$ edición, Madrid, Tecnos.

Chinkin, Ch., (1989) "The Challenge to Soft Law, Development and Change in International Law", 38 International Comparative Law Quarterly (1989), 850.

Gallaroti, G.M. (2010), Cosmopolitan Power in International Relations. A Synthesis of Realism, Neoliberalism and Constructivism, Cambridge, Cambridge University Press.

García, C. (2017), "Westfalia, Worldfalia, Eastfalia.El impacto de las transformaciones de la estructura de poder interestatal en el orden internacional”, Revista Española de Derecho Internacional, vol. 69, núm. 2, pp. 45-70.

García, C. (2021), "La construcción de normas globales entre el avance del cosmopolitismo blando y el retorno a la geopolítica. La regulación global de la ciberseguridad", Cursos de Derecho Internacional y Relaciones internacionales de Vitoria-Gasteiz, Valencia, Tirant lo Blanch, pp. 266-330

García, C. y Pareja, P. (2016), "La inspiración cosmopolita de la Responsabilidad de Proteger: construcción normativa y disensos”, en García Segura, C. (ed.), La tensión cosmopolita: avances y límites en la institucionalización del cosmopolitismo, Madrid, Tecnos, 2016, pp. 64-116.

Guzzini, S. (ed.) (2013), The Return of Geopolitics in Europe? Social Mechanisms and Foreign Policy Identity Crises, Cambridge, Cambridge University Press.

Ikenberry, G.J. (2018), “The end of liberal international order?”, International Affairs 94 (1), pp. 7-23.

Khagram, S.J., Riker, V., y Sikkink, K. (2002), Restructuring World Politics: Transnational Social Movements, Networks, and Norms, Minneapolis, University of Minnesota Press.

Rodrigo, A.J. (2019), "Más allá del Derecho internacional: el Derecho internacional público”, en R. Méndez-Silva, Derecho internacional, México DF, UNAM/El Colegio Nacional, pp. 67-98. 